\title{
Analisis Kecenderungan Informasi Terkait Covid-10 Berdasarkan Big Data Sosial Media dengan Menggunakan Metode Data Mining
}

\author{
Enda Esyudha Pratama ${ }^{1}$, Helen Sastypratiwi ${ }^{2}$, Yulianti $^{3}$ \\ 1,2,3 Jurusan Informatika, Fakultas Teknik, Universitas Tanjungpura \\ enda@informatika.untan.ac.id, ${ }^{1}$ helen@informatika.untan.ac.id, ${ }^{3}$ yulianti@informatika.untan.ac.id
}

\begin{abstract}
Abstrak
Wabah virus CORONA (COVID-19) mulai menginfeksi hampir ke seluruh negara di awal tahun 2020 tak terkecuali di Indonesia. Pemerintah selaku pihak yang berkepentingan mengeluarkan beberapa kebijakan terkait penanganan virus ini. Kebijakan tersebut mendapat berbagai tanggapan dari masyarakat terutama di media sosial. Jumlah tanggapan yang banyak dan beragam akan menjadi sebuah big data. Big data tersebut dapat menghasilkan informasi yang berharga jika diolah secara baik dan benar. Salah satu informasi yang dapat dihasilkan adalah analisis sentimen. Tujuan dari penelitian ini adalah mengetahui kecenderungan informasi berupa sentimen masyarakat di media sosial terhadap kebijakan pemerintah dalam penanganan covid-19. Proses klasifikasi sentimen secara otomatis dapat diselesaikan dengan pendekatan data mining. Data mining merupakan salah satu metode yang digunakan untuk menggali informasi penting dari sebuah tumpukan data yang berjumlah besar. Pada penelitian ini digunakan 1400 tweet. Kata kunci (keyword) yang digunakan terkait kebijakan pemerintah bersumber dari beberapa media online. Adapun kata kunci yang dipilih yaitu Social Distancing, Isolasi Mandiri, Karantina Wilayah, WFH, PSBB, Lockdown, dan Rapid Test. Kata kunci ini digunakan sebagai acuan untuk menarik data tweet dari Twitter. Dari setiap kata kunci tersebut akan dilakukan proses klasifikasi sentimen secara otomatis sehingga didapat data atau tweet yang dikelompokan ke dalam kelas sentimen positif, negatif, dan netral. Dari hasil penellitian yang dilakukan, sentimen masyarakat di media sosial terhadap kebijakan pemerintah dalam menanggulangi wabah virus ini cenderung positif.
\end{abstract}

Kata kunci : covid-19, kecenderungan informasi, kebijakan pemerintah, sentimen, data mining

\section{Pendahuluan}

Virus CORONA atau yang lebih dikenal dengan nama COVID-19 telah menjadi pandemi di awal tahun 2020. Virus ini pertama kali berasal dari China, tepatnya di kota Wuhan, telah menyebar secara cepat hampir keseluruh dunia termasuk Indonesia. Indonesia melalui Badan Nasional Penanggulangan Bencana (BNPB) telah menetapkan status darurat bencana terkait virus ini. Dalam rangka menanggulangi wabah pandemi tersebut, pemerintah Indonesia telah mengeluarkan beberapa kebijakan yang diharapkan dapat mengatasi penyebaran virus tersebut (Hikmawan, 2020).

Berbagai komentar pro-kontra masyarakat terkait kebijakan tersebut sangat beragam. Komentar-komentar tersebut dapat dilihat dari sosial media yang merupakan salah satu sarana bagi siapa saja untuk memberikan pendapatnya secara bebas. Salah satu media sosial yang paling banyak digunakan oleh masyarakat untuk berkomentar dan mengeluarkan pendapat terkait Covid-19 adalah Twitter (Kurniawan, 2020). Data dari tweet dapat dijadikan sebagai sumber data yang besar. Tentu komentar-komentar tersebut dapat memberikan informasi yang berguna jika dapat diolah secara tepat (Syarifuddinn, 2020).
Salah satu metode yang dapat digunakan untuk mengolah data yang besar adalah data mining (Pratama, 2020). Pada data mining terdapat serangkaian proses mulai dari tahap awal berupa preproses himpunan data hingga pada pilihan metode-metode untuk menghasilkan informasi yang bernilai (Wati, 2019). Salah satu informasi yang dapat dihasilkan adalah analisis sentimen (Risnantoyo, 2020). Analisis sentimen akan mengelompokan polaritas dari sekumpulan teks untuk melihat bagaimana opini yang diberikan bersifat positif, negatif, atau netral (Kamal, 2019). Analisis sentimen biasanya digunakan untuk mengungkap opini publik terhadap suatu isu, kepuasan layanan, kebijakan berdasarkan data tekstual (Utama, 2019).

Berdasarkan uraian yang telah dijelaskan sebelumnya, maka tujuan penelitian ini adalah menganalisa kecenderungan informasi terkait Covid19 berdasarkan big data sosial media dengan metode data mining. Analisa kecenderungan informasi yang menjadi fokus dari penelitian ini adalah analisis sentimen terhadap kebijakan pemerintah terkait penanganan Covid-19.

2. Metodologi Penelitian 
Secara umum, tahapan penelitian ini dibagi menjadi tiga bagian utama yaitu: himpunan data, pemilihan dan penerapan metode data mining, dan menghasilkan informasi \& pengetahuan.

Pada tahapan himpunan data berbagai proses dilakukan mulai dari menentukan paramter kata kunci untuk crawling data dari sosial media, preproses terhadapa teks yang berhasil didapat, dan output dari tahapan ini adalah data yang sudah bersih dan siap diolah.

Selanjutnya untuk proses pemilihan dan penerapan metode data mining dapat dilakukan dengan bantuan beberapa tools untuk mengolah data menggunakan algoritma-algoritma tertentu.

Tahap terakhir yaitu mengolah hasil dari tahapan sebelumnya menjadi sebuah informasi yang bernilai. Output dari hasil tahap sebelumnya, umumnya berupa data tabel, statistik, rekapitulasi, dsb. Untuk menjadi sebuah informasi, perlu dibuat analisis dan kajian yang divisualisasikan dalam bentuk yang mudah dipahami oleh manusia sebagai user

\subsection{Data Penelitian}

Pada penelitian ini, objek data yang digunakan bersumber dari data twitter. Data tweet yang diambil berdasarkan kata kunci (keyword) tertentu yang berkaitan dengan kebijakan Covid-19. Setiap kata kunci, jumlah tweet yang digunakan sebanyak 200 tweet. Adapun penentuan kata kunci yang digunakan berdasarkan analisis terhadap beberapa sumber. Sumber yang digunakan yaitu media online yang terpercaya.

Setiap media online tersebut memuat artikel yang membahas tentang istilah-istilah yang muncul pada masa pandemi Covid-19. Dari beberapa sumber tersebut, kemudian dipilih beberapa istilah terkait kebijakan pemerintah yang muncul atau beririsan pada berbagai sumber tersebut. Adapun penentuan kata kunci yang digunakan dalam penelitian secara lebih detail dapat dilihat pada Tabel 1

Table 1. Daftar Kata Kunci Kebijakan Pemerintah Terkait COVID-19 dari Media Online

\begin{tabular}{|c|l|l|}
\hline $\begin{array}{c}\text { Sumber / } \\
\text { Media }\end{array}$ & \multicolumn{1}{|c|}{ Kata Kunci } & $\begin{array}{c}\text { Kebijakan } \\
\text { Pemerintah }\end{array}$ \\
\hline \multirow{5}{*}{ Kompas } & ODP, PDP, Suspect, & Pockdown, \\
& Positif, Lockdown, Social & Distancing, Isolasi, \\
& Karantina, WFH, Masker & Social \\
Distancing, & Isolasi, \\
& N95, Hand Sanitiser, & Karantina, \\
& Fasaynakes & WFH \\
\hline \multirow{5}{*}{ Detik } & ODP, PDP, OTG, & PSBB, Social \\
& Suspect, PSBB, Social & Distancing, \\
& Distancing, Physical & WFH, \\
& Distancing, WFH, & Karantina, \\
& Karantina, Isolasi, & Isolasi, \\
& Lockdown, Rapid test, & Lockdown, \\
& Swab Test, PCR, Positif, & Rapid Test, \\
& Epidemi, Pandemi, Herd & SWAB Test \\
\hline
\end{tabular}

\begin{tabular}{|c|l|l|}
\hline & $\begin{array}{l}\text { Immunity, Flattening } \\
\text { Curve }\end{array}$ & \\
\hline \multirow{5}{*}{ Alodokter } & Social Distancing, Isolasi, & Social \\
& Karantina, Lockdown, & Distancing, \\
& Flatteing Curve, PDP, \\
& ODP, OTG, OTG, Herd & Isolasi, \\
& Karantina, & Lockdown, \\
& Immunity, PSBB & PSBB \\
\hline \multirow{5}{*}{ Tirto } & ODP, PDP, Suspect, & Lockdown, \\
& Positif, Lockdown, Social & Social \\
& Distancing, Isolasi, & Distancing, \\
& Karantina, WFH, Wabah, & Isolasi, \\
& epidemi, Pandemi, Rapid & Karantina, \\
& Test, Antispetik, & WFH, Rapid \\
& Diinfektan & Test \\
\hline
\end{tabular}

Dari Tabel 1, dapat dillihat beberapa kata kunci terkait kebijakan pemerintah yang aka digunakan pada keyword pengambilan data pada twitter. Kata kunci yang hanya muncul satu kali tidak diikutsertakan. Kata kunci "isolasi" dan "karantina" diubah menjadi "isolasi mandiri" dan "karantina wilayah" berdasarkan data atau twit yang tersedia di twiiter. Adapun kata kunci yang digunakan dalam penelitian ini yaitu : Social Distancing, Isolasi Mandiri, Karantina Wilayah, WFH, PSBB, Lockdown, dan Rapid Test. Terdapat 7 kata kunci yang digunakan untuk proses pengambilan data tweet di Twitter.

\subsection{Proses Data Mining}

Data mining adalah proses yang Menggabungkan berbagai teknik statistik, matematika, kecerdasan buatan, dan machine learning untuk mengekstraksi dan mengidentifikasi informasi yang bermanfaat dan pengetahuan yang terkait dari data dalam jumlah yang besar (Han, 2006).

Data mining merupakan sebuah disiplin ilmu yang bertujuan untuk menemukan, menggali, atau menambang pengetahuan dari data atau informasi yang kita miliki. Data mining, sering juga disebut sebagai Knowledge Discovery in Database (KDD). KDD adalah kegiatan yang terdiri dari pengumpulan, pemakaian data, historis untuk menemukan keteraturan, pola atau hubungan dalam set data berukuran besar (Larose, 2005).

Secara garis besar metode pelatihan yang digunakan dalam teknik-teknik data mining dibedakan ke dalam dua pendekatan, yaitu (Putra, 2016): (1) Unsupervised learning, metode ini dierapkan tanpa adanya latihan (training) dan tanpa ada guru (teacher). Guru di sini adalah label dari data. (2) Supervised learning, yaitu metode belajar dengan adanya latihan dan pelatih. Dalam pendekatan ini, untuk menemukan fungsi keputusan, fungsi pemisah atau fungsi regresi, digunakan beberapa contoh data yang mempunyai output atau label selama proses training 
Ada beberapa teknik yang dimiliki data mining berdasarkan tugas yang bisa dilakukan (Muhammad, 2016):

1. Deskripsi, Para peneliti biasanya mencoba menemukan cara untuk mendeskripsikan pola dan trend yang tersembunyi dalam data.

2. Estimasi, Estimasi mirip dengan klasifikasi, kecuali variabel tujuan yang lebih kearah numerik dari pada kategori.

3. Prediksi, Prediksi memiliki kemiripan dengan estimasi dan klasifikasi. Hanya saja, prediksi hasilnya menunjukkan sesuatu yang belum terjadi (mungkin terjadi di masa depan).

4. Klasifikasi, Dalam klasifikasi variabel, tujuan bersifat kategorik. Misalnya, kita akan mengklasifikasikan pendapatan dalam tiga kelas, yaitu pendapatan tinggi, pendapatan sedang, dan pendapatan rendah.

5. Clustering, Clustering lebih ke arah pengelompokan record, pengamatan, atau kasus dalam kelas yang memiliki kemiripan.

6. Asosiasi, Mengidentifikasi hubungan antara berbagai peristiwa yang terjadi pada satu waktu.

Pada penelitian ini, pendekatan data mining digunakan pada teknik klasifikasi. Klasifikasi merupakan proses pengelompokan data ke dalam beberapa kategori atau label. Penelitian ini akan mengelompokan data ke dalam kelas-kelas sentimen. Kelas sentimen yang digunakan yaitu positif, negatif, dan netral. (Hikmawan, 2020)

Sebagai suatu rangkaian proses, data mining dapat dibagi menjadi beberapa tahap proses. Tahaptahap tersebut bersifat interaktif, pemakai terlibat langsung atau dengan perantaraan knowledge base. Tahap-tahap data mining adalah sebagai berikut $(\mathrm{Ge}$, 2017):

1. Pembersihan data (data cleaning)

Pembersihan data merupakan proses menghilang-kan noise dan data yang tidak konsisten atau data tidak relevan.

2. Integrasi data (data integration)

Integrasi data merupakan penggabungan data dari berbagai database ke dalam satu database baru.

3. Seleksi data (data selection)

Data yang ada pada database sering kali tidak semuanya dipakai, oleh karena itu hanya data yang sesuai untuk dianalisis yang akan diambil dari database.

4. Transformasi data (data transformation) Data diubah atau digabung ke dalam format yang sesuai untuk diproses dalam data mining

5. Proses mining

Merupakan suatu proses utama saat metode diterapkan untuk menemukan pengetahuan berharga dan tersembunyi dari data Evaluasi pola (pattern evaluation) Untuk mengidentifikasi pola-pola menarik ke dalam knowledge based yang ditemukan.

6. Presentasi pengetahuan (knowledge presentation)

Merupakan visualisasi dan penyajian pengetahuan mengenai metode yang digunakan untuk memperoleh pengetahuan yang diperoleh pengguna.

Secara umum, arsitektur sistem yang digunakan pada penelitian ini dapat dilihat pada Gambar 1.

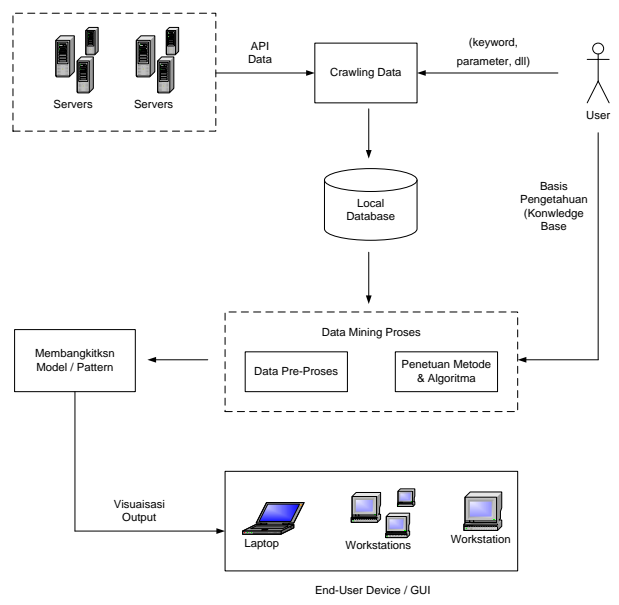

Gambar 1. Arsitektur Sistem Proses Data Mining

Data yang digunakan dari penelitian ini bersumber dari data sosial media. Beberapa sosial media yang ramai digunakan umumnya menyediakan fitur untuk dapat mengambil (crawling) data dengan metode akses API (Application Programming Interface). Data yang dapat diambil umumnya berupa postingan atau tulisan dari setiap pengguna menggunakan aturan perizinan yang ditentukan oleh sosial media tersebut.

Data yang diambil dari sosial media akan disimpan ke dalam lokal basisdata. Pada saat crawling data, parameter kata kunci didapat dari user dimana kata kunci ini dihasilkan dari proses studi literatur dan analisa pengetahuan dari peneliti. Selanjutnya data yang sudah tersimpan dalam lokal basis data akan dilakukan proses data mining.

Selanjutnya untuk proses data mining terdapat dua proses utama yaitu tahap pre-proses dan penerapan algoritma. Pada tahap pre-proses akan dilakukan proses pemilah kata (tokenize), filtering dengan menggunakan blacklist yaitu membuang kata-kata yang tidak mmpunyai makna. Selanjutnya pada tahap penerapan algoritma digunakan algoritma Naive Bayes untuk melakukan klasifikasi sentimen untuk setiap kata kunci (Juniarsih, 2020).

Tahap terakhir yaitu mengolah hasil dari tahapan sebelumnya menjadi sebuah informasi yang bernilai. Output dari hasil tahap sebelumnya, umumnya berupa data tabel, statistik, rekapitulasi, dsb. Untuk menjadi sebuah informasi, perlu dibuat 
analisis dan kajian yang divisualisasikan dalam bentuk yang mudah dipahami oleh manusia sebagai user. Bentuk visualisasi dapat berupa, grafik, maupun narasi tulisan

\section{Hasil dan Analisis}

Pada penelitian ini, digunakan tools Jupyter berbasis bahasa pemograman Pyhton untuk melakukan proses klasifikasi sentimen. Beberapa library yang digunakan yaitu tweepy, nltk, dan matplotlib. Tweepy berfungsi sebagai library untuk melakukan koneksi ke twiiter dengan standar aturan verfikasi yang telah ditentukan oleh twitter yaitu Oauth dan REST API arsitektur.

Proses pengumpulan data dari twitter dilakukan dengan tools Jupyter berbasis bahasa python dengan library tweepy. Agar dapat terkoneksi dengan twitter, aplikasi yang dibuat harus memiliki semacam kunci atau key yang dihasilkan dari twitter. Terdapat 4 jenis kunci yang dibutuhkan untuk ditaruh di dalam kode program yaitu: access token, access secret, consumer API keys dan consumer secret. Halaman untuk mendapatkan kunci tersebut yaitu: https://developer.twitter.com/en/apps (Sembodo, 2016)

Pengguna melakukan proses pendaftaran di halaman tersebut dengan memberikan beberapa informasi yang dibutuhkan. Data-data tersebut berguna untuk Twitter dalam meverifkasi kebutuhan kita dalam mebuat aplikasi.

Jika memenuhi syarat yang ditentukan, maka proses verfikasi akan diterima. Setelah proses verfikasi diterima, maka akses kunci (key) akan didapat seperti terlihat pada Gambar 2.

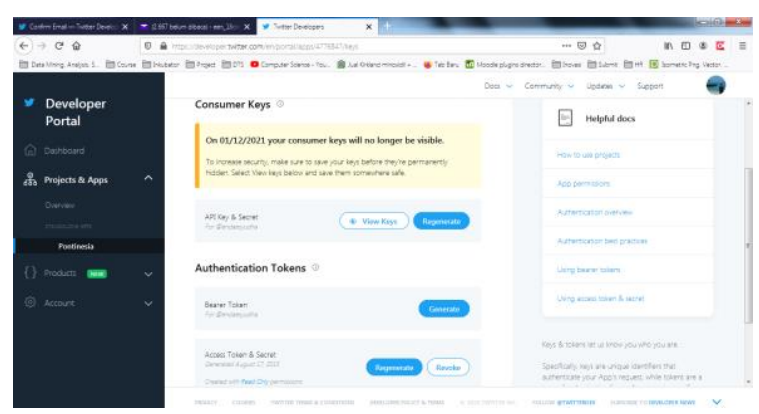

Gambar 2. Halaman informasi keys dan tokens

Pada halaman tersebut terdapat beberapa informasi yang kita butuhkan terkai akses consumer keys dan access tokens. API keys bersifat unik untuk setiap aplikasi yang kita buat. Sedangkan access tokens akan selalu generate ketika kita membutuhkan untuk melihatnya. Tampilan untuk melihat API key seperti pada Gambar 3.

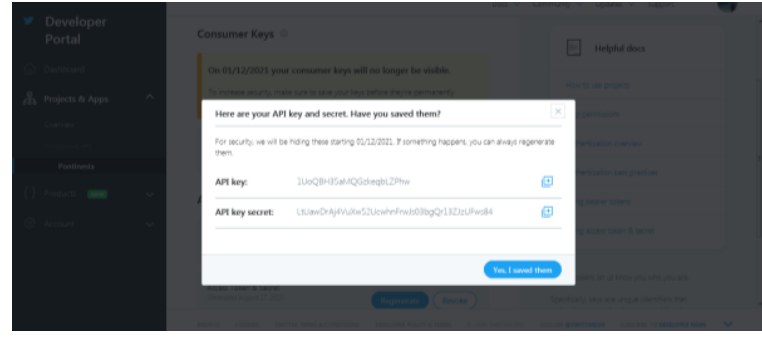

Gambar 3. Halaman untuk melihat API keys dan tokens

Setelah diverfikasi oleh twitter, aplikasi dapat melakukan proses crawling data dengan parameter tertentu. Beberapa paramater yang perlu dimasukan adalah kata kunci (keyword) dan jumlah tweet. Data twitter yang dapat diambil dalam jangka rentang waktu maksimal satu bulan terakhir. Tampilan dari proses pengumpulan data dilihat pada Gambar 4.

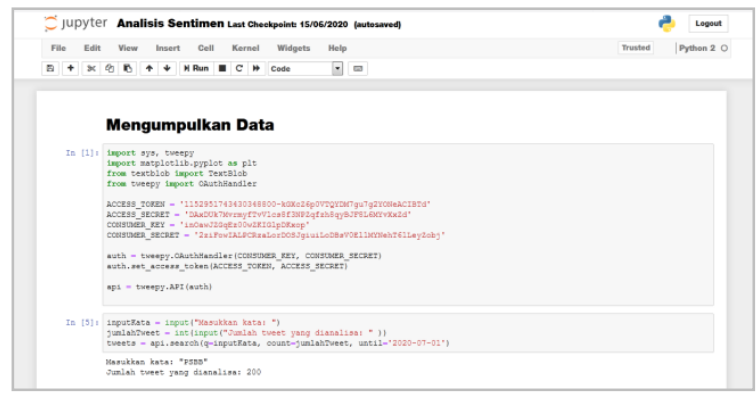

Gambar 4. Proses Pengumpulan Data Tweet Menggunakan Tools Jupyter

Selanjutnya setelah data dari twitter didapat, proses selanjutnya adalah proses data mining. Pada tahap pertama dilakukan proses preproses data. Proses diawali dengan melakukan pemenggalan setiap kata. Kemudian proses filtering yaitu membuang kata, simbol, dan berbagai karakter lainnya yang tidak mempunyai makna. Python juga telah menyediakan data stopword khusus untuk bahasa Indonesia. Stopword merupakan kumpulan kata yang tidak mempunyai makna dan daam prosesnya akan dihapus atau dibuang.

Setelah dilakukan preproses, maka tahap selanjutnya yaitu proses klasifikasi menggunakan algoritma Naive Bayes. Proses klasifikasi ini dilakukan dengan membangkitkan model yang selanjutnya dapat digunakan untuk mengklasifikasikan data-data baru yang belum mempunyai kelas sentimen. Untuk mempermudah visuliasi output, maka hasil klasifikasi ditampilkan dalam bentuk pie chart. Adapun tampilan program dapat dilihat pada Gambar 5. 


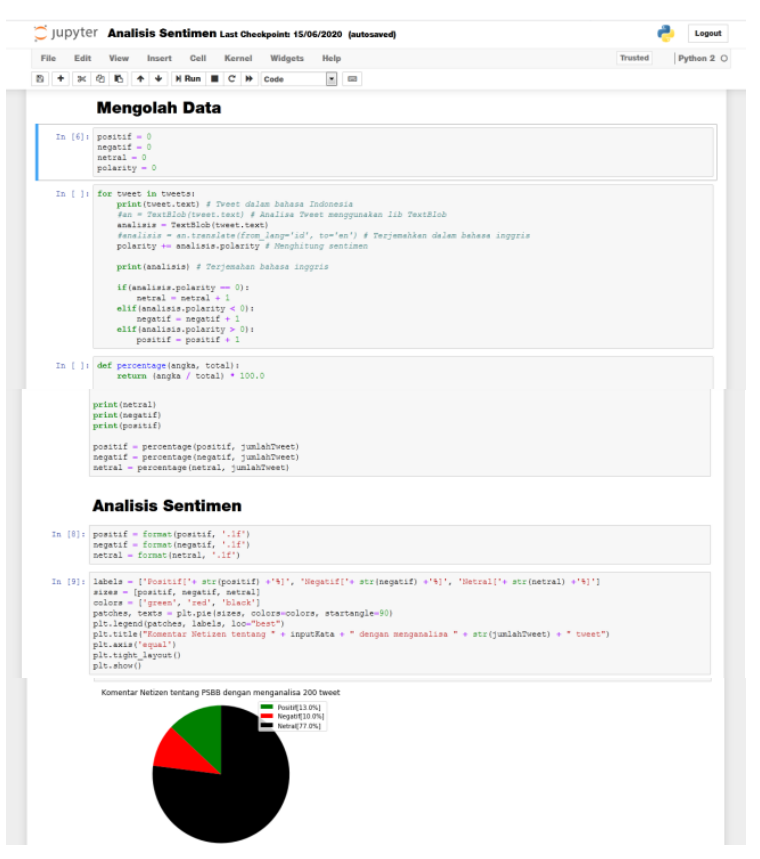

Gambar 5. Proses Klasifikasi Sentimen dan Visualisasi Output

Proses ini dilakukan berulang-ulang pada setiap kata kunci yang telah ditentukan sebelumnya. Persentase nilai pada setiap kata kunci didapat dengan cara membandingkan data yang termasuk pada suatu kelas sentimen degan jumlah seluruh data. Hasil klasifikasi sentimen dari setiap kata kunci dapat dilihat pada Tabel 2.

Table 2. Hasil Klasifikasi Sentimen

\begin{tabular}{|c|c|c|c|}
\hline Kata Kunci & $\begin{array}{c}\text { Positif } \\
(\mathbf{\%})\end{array}$ & $\begin{array}{c}\text { Negatif } \\
(\mathbf{\%})\end{array}$ & $\begin{array}{c}\text { Netral } \\
(\mathbf{\%})\end{array}$ \\
\hline Social Distancing & 67 & 23 & 10 \\
\hline PSBB & 23 & 8 & 69 \\
\hline $\begin{array}{c}\text { WFH (work from } \\
\text { home) }\end{array}$ & 31 & 19 & 50 \\
\hline Isolasi Mandiri & 4 & 1 & 95 \\
\hline Karantina Wilayah & 12 & 70 & 18 \\
\hline Lockdown & 26 & 16 & 58 \\
\hline Rapid Test & 12 & 9 & 79 \\
\hline
\end{tabular}

Berdasarkan hasil klasfikasi dapat dianalisa beberapa informasi terkait kebijakan pemerintah terkait penanganan wabah covid-19 di Indonesia. Komentar masyarakat di sosial media cenderung positif meskipun jumlahnya jauh dari sentimen yang bersifat netral.

Jika dilihat secara lebih spesifik, sentimen netral banyak dihasilkan dari tweet akun mediamedia online yang cenderung bersifat memberikan infromasi. Umumnya tweet dari akun-akun tersebut berupa judul dari berita yang terdapat di website.
Sehingga cenderung tidak termasuk pada kelas positif maupun negatif.

Hal menarik lainnya yang dapat dilihat yaitu, masyarakat cenderung positif akan kebijakan pemerintah terkait PSBB dan Lockdown, namun cenderung kurang setuju atau negatif terhadap kebijakan Karantina Wilayah. Sedangkan untuk kebijakan isolasi mandiri nilainya cenderung kecil. Hal ini disebabkan istilah isolasi mandiri cenderung bukan kebijakan, melainkan langkah penyembuhan bagi pasien yang sudah postifi terinfeksi virus sehingga cenderung tidak tepat jika dianggap sebagai kebijakan.

\section{Kesimpulan dan Saran}

Media sosial sebagai sarana masyarakat untuk memberikan komentar dapat menjadi salah satu sumber data yang bermanfaat jika diolah dengan baik dan benar. Twitter merupakan saah satu media sosial yang dapat digunakan untuk mengumpukan data terkait opini masyarakat tentang sesuatu. Berbagai fitur telah disedaikan oleh twitter untuk dapat digunakan sesuai dengan kebutuhan. Pada penelitian ini menggunakan data dari twitter untuk 7 kata kunci (keyword) dimana setiap kata kunci diperoleh 200 tweet sehingga total data yang digunakan yaitu 1400 tweet.

Data mining merupakan salah satu metode yang dapat digunakan untuk mengolah tumpukan data dalam jumlah yang besar. Pada penelitian ini, salah satu metode pada data mining yang diterapkan yaitu klasifikasi dengan algoritma naive bayes. Klasifikasi yang digunakan pada penelitian ini yaitu klasifikasi sentimen dengan tiga kelas yaitu: positif, negatif, netral. Dari hasil penellitian yang dilakukan, sentimen masyarakat di media sosial terkait kebijakan pemerintah cenderung positif.

Penelitian lebih lanjut dapat dilakukan terkait pengembangan algoritma atau penilihan tugas lain pada data mining. Sebagai contoh, terkait analisis estimasi atau prediksi kebijakan yang dapat berasosiasi dengan kebijakan lainnya. Selain itu, terkait pemilihan keyword untuk penggalian dataset dapat lebih diperluas.

\section{Daftar Pustaka:}

Hikmawan, S., Pardamean, A., \& Khasanah, S. N. (2020). Sentimen Analisis Publik Terhadap Joko Widodo terhadap wabah Covid-19 menggunakan Metode Machine Learning. Jurnal Kajian Ilmiah, 20(2), 167-176.

Ge, Z., Song, Z., Ding, S.X. and Huang, B., (2017). Data mining and analytics in the process industry: The role of machine learning. IEEE Access, 5, pp.20590-20616.

Han, J. dan M. Kamber. (2006). Data Mining: Concepts and Techniques, Second Edition. Morgan Kaufmann Publishers. San Francisco 
Juniarsih, S., Ripanti, E. F., \& Pratama, E. E. (2020) Implementasi Naive Bayes Classifier pada Opinion Mining Berdasarkan Tweets Masyarakat Terkait Kinerja Presiden dalam Aspek Ekonomi. JUSTIN (Jurnal Sistem dan Teknologi Informasi), 8(3), 239-249.

Kamal, R. M. (2019). Analisis Sentimen Cyberbullying Pada Komentar Facebook Dengan Metode Klasifikasi Support Vector Machine (Doctoral dissertation, Universitas Komputer Indonesia)

Kurniawan, R., \& Apriliani, A. (2020). Analisis Sentimen Masyarakat Terhadap Virus Corona Berdasarkan Opini dari Twitter Berbasis Web Scraper. Jurnal INSTEK (Informatika Sains dan Teknologi), 5(1), 67-75

Larose, D.T. (2005). Discovering Knowledge in Data: An Introduction to Data Mining.

Muhammad, H., Sudrajat, R., and Rosadi, R. (2016). Penerapan Data Mining Dalam Menganalisis Kepribadian Pengguna Media Sosial Dengan Naïve Bayes Classifier: Studi Kasus Media Sosial Instagram. Jurnal Informatika Universitas Padjadjaran

Pratama, E. E., \& Ripanti, E. F. (2020, February). Analysis of Student Academic Performance and Social Media Activities by Using Data Mining Approach. In Proceedings of the 2020 The 6th International Conference on EBusiness and Applications (pp. 111-115).

Putra, I. B. G. W., Sudarma, M., \& Kumara, I. N. S. (2016). Klasifikasi Teks Bahasa Bali dengan Metode Supervised Learning Naive Bayes Classifier. Teknologi Elektro, 15(2), 81-86.

Risnantoyo, R., Nugroho, A., \& Mandara, K. (2020). Sentiment Analysis on Corona Virus Pandemic Using Machine Learning Algorithm. JITE (JOURNAL OF INFORMATICS AND TELECOMMUNICATION ENGINEERING), 4(1), 86-96.

Sembodo, J. E., Setiawan, E. B., \& Baizal, Z. A. (2016, August). Data Crawling Otomatis pada Twitter. In Indonesian Symposium on Computing (Indo-SC) (pp. 11-16).

Syarifuddinn, M. (2020). Analisis Sentimen Opini Publik Mengenai Covid-19 Pada Twitter Menggunakan Metode Naïve Bayes Dan KNN. Inti Nusa Mandiri, 15(1), 23-28.

Utama, H. S., Rosiyadi, D., Prakoso, B. S., \& Ariadarma, D. (2019). Analisis Sentimen Sistem Ganjil Genap di Tol Bekasi Menggunakan Algoritma Support Vector Machine. Jurnal RESTI (Rekayasa Sistem dan Teknologi Informasi), 3(2), 243-250.

Wati, A., Indriani, I., Manihuruk, T. S. S., Sintya, S., Manurung, I. Y., \& Windarto, A. P. (2019). Implementasi datamining pada kasus tenaga listrik yang dibangkitkan berdasarkan provinsi. KOMIK (Konferensi Nasional Teknologi Informasi dan Komputer), 3(1). 